\title{
Clinical Study Data Element
}

National Cancer Institute

\section{Source}

National Cancer Institute. Clinical Study Data Element. NCI Thesaurus. Code C142437.

A data element associated with a clinical study. 